\title{
Strategy of Diffusion and Its Impacts on the Translation of Meditation Text
}

\author{
Made Susini \\ Warmadewa University, Bali, Indonesia \\ I Nengah Sudipa \\ Udayana University, Bali, Indonesia \\ I Nyoman Suparwa \\ Udayana University, Bali, Indonesia \\ Ida Ayu Made Puspani \\ Udayana University, Bali, Indonesia
}

\begin{abstract}
This research concerns with the strategy of diffusion applied in the translation of Indonesian meditation text into English. Applying SFL of Halliday (2014), translation as re-contextualization (House, 2015) and translation strategies (Malone, 1988), it focuses on the impacts of the strategy of diffusion upon the target text transitivity structure and clause types. The result of this research shows that the strategy of diffusion causes shifts of transitivity structure which include dematerialization, expansion and the shift from mental into non-mental clause. When there is dematerialization, the clause type changes are: (a) material clause of event to relational clause of identification; (b) material clause of event to relational clause of attributive; (c) material clause of event to relational clause of attributive with Attributor; (d) material clause of action to relational clause of attributive; (e) material clause of action to relational clause of attributive/possessive; and (f) material clause of action to relational clause of identification. In the expansion, the nominalization construction turns into material clause, relational clause of attributive and mental clause of desiderative and cognitive. In the shift from mental into non-mental clause, mental clause of cognitive and desiderative becomes relational clause of attributive.
\end{abstract}

Index Terms - translation strategy, diffusion, re-contextualization, transitivity structure, clause type

\section{INTRODUCTION}

Meditation text contains language of mental building and its goal is to persuade people to act in a certain way as suggested by the speaker. This type of text can guide people to have a mentally happy life. Text of meditation is as important as other texts, such as those of religious texts and it concerns with culture. Since the meaning of this text is influenced by culture, problems may arise to understand it when the text is translated into different language. This is because of the different ways to convey the persuasive meaning of meditation among languages. By this phenomenon, research on the translation of meditation text needs to be explored.

This present study concerns with the translation of meditation text from Indonesian into English. This text is composed of some types of clause. Based on Systemic Functional Linguistics (SFL) proposed Halliday (2014), clause type deals with transitivity structure and transitivity refers to how meaning is represented to express experience of the world in the form of a clause (p. 219). Transitivity structure consists of three components which include participant, process (Pro) and circumstance (Circum). The types of clause are categorized based on the type of process used in a clause, whether it is material, verbal, mental, behavioral, relational or existential. This transitivity structure can describe who does the action, what action someone does and when, where and how the action is done. This indicates that the persuasive meaning of a text can also be analyzed from the realization of the process types being used (Darani, 2014, $\mathrm{p}$. 179).

When the persuasive meaning realized by a particular transitivity structure in meditation text is translated from Indonesian into English, it causes problem in translation. It is due to the difference between Indonesian and English which are linguistically and culturally different. Adjustment by re-contextualizing the source text (ST) must be made in order that the English text is accepted as natural language for the speakers of English. Re-contextualization in translation includes all aspects and varies depending on the types of text to be translated. For instance, to translate English movie titles, the aspects to be considered among others are faithfulness, cultural awareness, combination of merchant and aesthetic quality, artistic quality and appropriate translation strategy (Bai, 2018, p. 124). Since the translation strategy applied in translation also can influence the target text, this becomes an important object of research to be concerned. 
Numerous researches on translation strategies have been conducted by the previous researchers, but their works were mostly on the translation strategies of other text types, among those are movie titles, legal text (Bai, 2018; Aghagolzadeh, 2012). This study concerns with other text type and focuses on the translation strategy of diffusion as one of the strategies applied in the translation of meditation text from Indonesian into English. This strategy is used by the translator to bridge the cultural and linguistic differences between Indonesian and English. Nine translation strategies can be applied in translation (Malone, 1988, p. 15). The strategies are used by the translator as a method to achieve the translation equivalence, so the result of the translation is influenced by the strategy applied. Translation strategy of diffusion as a repacking strategy using more expansively target text construction can also impact on the target text. Applying Systemic Functional Linguistics (SFL) by Halliday (2014), House's translation as recontextualization (2015) and Malone's translation strategies (1988), this study is to answer the following questions:

a. What shifts of transitivity structure occur in the translation of meditation text from Indonesian into English when the strategy of diffusion is applied?

b. What are the impacts of the shifts on the English text?

\section{THEORETICAL FRAMEWORK}

The translation of meditation text concerns with how language in the field of meditation is structured in Indonesian and how it is re-expressed in English. The language used in meditation text is influenced by the context of the source and target text (TT). The contextual factor plays an important role in using language and this means that besides translation theory, this translation study also needs a functional linguistic theory which can define the use of language in context. The functional linguistics applied in this study is Systemic Functional theory proposed by Halliday (2014) and the translation theories include House's translation as re-contextualization (2015) and Malone's translation strategies (1988).

\section{A. Systemic Functional Linguistics (SFL)}

As translation concerns with language in use, the text to be translated and its equivalent must be analyzed with its context. Language and context cannot be separated since they coherence each other. The translator as the producer of the target text must work with this concept. The language used as the equivalent of the source text must be in accordance with the meaning to be transferred and to what purpose the language is used. This shows that translation deals with language as choice. Systemic Functional Linguistics (SFL) proposed by Halliday (2014) is a theory which also defines language as a choice. The grammatical structure someone uses must depend on the functions of the language, whether the language used is to convey ideational, interpersonal or textual meaning and whether it is used to express experience of the world, to make interpersonal relation or to create textual chain.

When the language is used to express experience of the world, it is realized by transitivity structure in the form of a clause. Transitivity structure is composed of three components. They are participant, process and circumstance. There are six types of process which include process of material, mental, verbal, behavioral, relation and existential. The type of clause is categorized based on the type of process used. The types of clause based on SFL include clause of material, mental, verbal, behavioral, relation and existential. Transitivity structure is a configuration of the three components and this structure can inform the reader what is the text about, who involves in it and how, when and where it is done. The functional equivalence in translation can also be analyzed from the transitivity structures of the source and target texts.

\section{B. Translation Equivalence and Translation Strategies}

Translation does not only concern with linguistic forms, it also deals with how the linguistic form is used for a particular context. House (2015) mentions that translation is considered as the replacement of a text in the source language by a semantically and pragmatically equivalent text in the target language (p. 23). Based on this opinion, an adequate translation text is a text which is semantically and pragmatically equivalent. To achieve a text which is equivalent as mentioned by House (2015), adjustment must be made by the translator in all ranks and transitivity structure is no exception to this connection. In the process of adjustment, there is possibility that shifts of transitivity structures occur in translation and the shifts can be obligatory or optional (Baker, 2001, p. 228). Shifts in translation if seen from its transitivity structure include the changes from material clause into non-material, from material into material clause, from mental clause into non-mental, and some other changes. Pérez (2007) mentioned some cases of translation shifts, such as a) dematerialization: material clause in the source text to non-material clause in the target text; b) materialization: non-material clause in the source text to material clause in the target text; c) expansion: no process in the source text to clause with process; d) contraction: clause with process in the source text to no process in target text; and shifts from one type of material clause to another type of material clause (p. 152).

The types of changes which occur in translation depend to some extent on the translation strategies applied. Malone (1988) suggested nine strategies in translation (p. 15). The strategies include equation, substitution, divergence, convergence, amplification, reduction, diffusion, condensation and reordering. The first eight strategies are grouped as: matching which includes equation and substitution; zigzagging (divergence and convergence); recrescence (amplification and reduction); and repacking (diffusion and condensation). Quoted from Malone (1988), diffusion as the 
focus of this present study refers to repacking strategy by which a source element or construction is in some sense rendered by a more loosely or expansively organized target text (p. 55).

\section{RESEARCH METHOD}

The data of this study were taken from an Indonesian book of meditation entitled Butir-Butir Kebijaksanaan: Titian Hidup Sehat dengan Meditasi Bio-Energi Ratu Bagus (Ida Pandita Mpu Nabe Parama Daksa Natha Ratu Bagus, 2012) which functions as the source text and its translation in English entitled Pearls of Wisdom: The Path of a Healty Life with Ratu Bagus Bio-Energy Meditation (Stacey, 2014). This study is a descriptive qualitative study and carried out in some steps.

Firstly, functional grammatical analysis method was applied to analyze the types of clause found in the data source. The clauses found in the SL were divided into their constituents referring to transitivity structures of Halliday (2014, p. 213) to identify their types of clause. The transitivity structure was determined by identifying the type of process used in the clause. Secondly, the types of clause of the ST and TT were compared to identify whether there are differences in their transitivity structures. The translation strategies applied to translate the clauses of the ST were then examined. When there is a kind of repacking through expansion in the translation analyzed, this shows that the translation applied is the strategy of diffusion. All clauses which are translated by strategy of diffusion were marked. The last procedure is identifying the impacts of the translation strategy of diffusion. The impacts were evaluated from the changes of the types of transitivity shift and the kinds of clause types which occur. The types of transitivity shift were examined by identifying the changes of its transitivity structure and the changes of the clause types were examined by identifying the type of process used in the clause under study.

\section{RESUlT AND DisCUSSION}

The translation strategy of diffusion as a repacking strategy to some extent affects the TT construction. This strategy makes the TT have a more expansively organized construction when compared to the ST without changing its meaning. In terms of the translation at clause level, there are some data which show the impacts of the strategy of diffusion on the TT. Some clause types change and some shifts of transitivity structure occur. The types of shift affected by the strategy of diffusion include shift of dematerialization, expansion and shift from mental into non-mental clause. The types of transitivity shifts and changes of clause types are elaborated in the following data.

\section{A. Diffusion and Shift of Dematerialization}

The strategy of diffusion causes the occurrence of dematerialization shift in translation. Dematerialization refers to shifts of transitivity in translation by which material clause is rendered by non-material clause as seen in the following data.

(1) ST: Sepanjang ada kemauan untuk selalu berpikir positif, maka kemauan tersebut yang akan membimbing kita (p. 88).

TT: As long as we always have the desire to think positively, it will be our guide (p. 88).

The dematerialization shift resulted by the strategy of diffusion causes the change of clause type. The change is seen from the type of process used. In this datum, material clause of event (Mat/event) in the ST changes into clause relational clause of identification (Rel/ident) in the TT. The source process represented by 'akan membimbing' as found in the following example is translated by repacking it using more words in the TT without changing its semantic content. The TT is represented by 'will be one's guide' in the TL. The process in the ST realized by verb is realized by be plus noun in the TT. By this changing, the translator wants to make the TT more categorical by directly mentioning the role of the subject. That is as a guide.

\begin{tabular}{|l|l|l|l|l|l|l|l|}
\hline \multirow{3}{*}{$(1)$} & \multirow{2}{*}{ ST } & kemauan & tersebut & yang & \multicolumn{2}{|c|}{ akan membimbing } & kita \\
\cline { 2 - 7 } & \multirow{2}{*}{ AT } & Actor & \multicolumn{3}{|l|}{ Pro: Mat/event } & Goal \\
\cline { 2 - 7 } & \multirow{2}{*}{ it } & & will & be & guide & $1^{\text {st }}$ Person pl. ( POSS) \\
\cline { 2 - 7 } & & Token & $\varnothing$ & Pro: Rel/ident & Value & \\
\hline
\end{tabular}

The same case also happens to the following data. There are shifts of dematerialization as a result of the diffusion strategy.

(2) ST: Organ tubuh kita akan memberikan yang terbaik untuk kita sepanjang tubuh tersebut tidak tertekan (p. 117).

TT: Our physical organs will give us the best when the body is not under stress (p. 117).

(3) ST: Kalau jiwa kita bekerja, maka itu artinya kita sudah berada dalam frekwensi spiritual (p. 125).

TT: If our Soul is at work it means that we are ready in the spiritual frequency (p. 125).

The material clause of event (Mat/event) represented by processes of 'tertekan' and 'bekerja' is rendered by relational clause of attribute (Rel/attrib) in the TT. More words are also used to translate the source process which is in one word, but in these data the process of the ST is realized by be plus adjective in the TT represented by 'is under stress' and 'is at work'. The ST is repacked by the translator in the TT to make the TT more static. The change of the process used is elaborated in the following. 


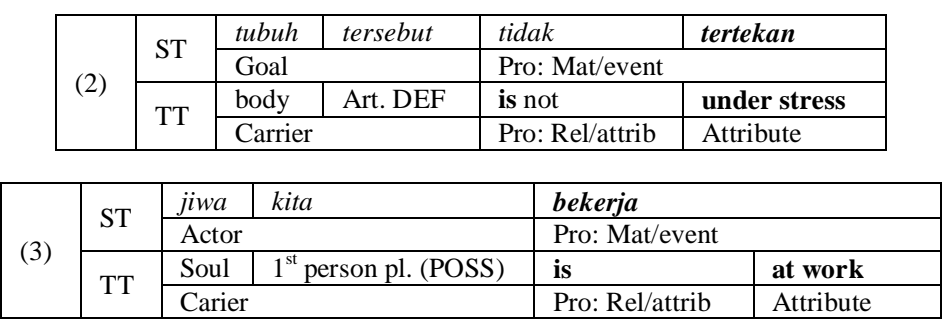

The example below elaborates that to translate material clause of event/operative by the strategy of diffusion, a participant functioning as Attributor is needed and the process realized by a verb is translated into a verb having meaning of causing and adjective form.

(4) ST: Oleh karena itu, marilah kita latihan secara serius dan api suci itu akan membersihkan diri kita, ... (p. 92)

TT: Let's therefore train seriously so that the sacred fire can make us (be) clean ... (p. 92).

In this datum it is found that 'membersihkan' is repacked using more words into 'make clean' in the TT and the TT is in the form of relational clause of attributive (Rel/attrib). In this translation the translator softens the message by presenting an Attributor in the TT and this makes the the TT more static.

\begin{tabular}{|l|l|l|l|l|l|l|l|l|l|}
\hline \multirow{3}{*}{ (4) } & \multirow{2}{*}{ ST } & \multicolumn{2}{|l|}{ api suci } & itu & akan & membersihkan & diri & kita & \\
\cline { 2 - 9 } & \multirow{2}{*}{$\mathrm{TT}$} & Actor & sacred fire & Art. DEF & $\varnothing$ & Pro: Mat/event/operat & Goal & & \\
\cline { 2 - 9 } & & Attributor & & can make & Pro- & Carrier & (be) & -cess: Rel/attrib & Attribute \\
\hline
\end{tabular}

The following data use material clause of action/ receptive (Mat/action/recept) and action/operative (action/operat) to realize experience of the world.

(5) ST: Vibrasi ini juga dapat digunakan untuk menghindari pertikaian (p. 132).

TT: This vibration is also useful for avoiding conflicts (p. 133).

(6) ST: Mereka akan selalu menolong (p. 163).

TT: They are always helpful (p. 163).

When they are rendered by applying strategy of diffusion, more words are used. The processes of both types of clause represented by 'digunakan' and 'menolong' are rendered by be plus adjective which is realized by 'is useful and 'are helpful' in the TT. This is also a kind of a repacking process by turning the ST into relational clause of attributive (Rel/attrib) and the TT becomes more static by this construction. This also shows that the speaker gives more emphasize to the result and not to the action.

\begin{tabular}{|c|c|c|c|c|c|c|c|c|c|c|c|}
\hline \multirow{4}{*}{ (5) } & \multirow{2}{*}{ ST } & Vibrasi & & ini & \multirow{2}{*}{$\begin{array}{l}\text { juga } \\
\text { Circum. }\end{array}$} & dapa & \multicolumn{2}{|c|}{ digunakan } & untuk & menghindari & pertikaian \\
\hline & & \multicolumn{3}{|l|}{ Goal } & & \multicolumn{3}{|c|}{ Pro: Mat/action/recept } & \multicolumn{3}{|c|}{ Circum } \\
\hline & \multirow{2}{*}{$\mathrm{TT}$} & \multirow{2}{*}{\multicolumn{2}{|c|}{$\begin{array}{l}\text { Vibration } \\
\text { Carrier }\end{array}$}} & \multirow[t]{2}{*}{ Art. DEF } & \multirow{2}{*}{$\begin{array}{l}\text { also } \\
\text { Circum }\end{array}$} & \multirow{2}{*}{\multicolumn{2}{|c|}{\begin{tabular}{l|l}
$\varnothing$ & is \\
Pro: Rel/Attrib \\
\end{tabular}}} & \multirow{2}{*}{$\begin{array}{l}\text { useful } \\
\text { Attribute } \\
\end{array}$} & for & avoiding & conflict \\
\hline & & & & & & & & & \multicolumn{2}{|c|}{ Circum } & \\
\hline & & \multirow{4}{*}{ (6) } & \multirow[b]{2}{*}{ ST } & & \multicolumn{2}{|c|}{ akan } & selalu & \multicolumn{3}{|c|}{ menolong } & \\
\hline & & & & Actor & \multirow{2}{*}{\multicolumn{2}{|c|}{ Time(future) }} & Circum & \multicolumn{3}{|c|}{ Pro: Mat/act } & \\
\hline & & & \multirow{2}{*}{ TT } & They & & & lways & \multicolumn{2}{|c|}{ are } & helpful & \\
\hline & & & & Carrier & & & ircum & Pro: $\mathrm{Re}$ & trib & Attribute & \\
\hline
\end{tabular}

Strategy of diffusion also can turn material clause of action/operative (Mat/action/operat) into material clause of relational/attributive/possessive (Rel/attrib/poss) as found in the following data.

(7) ST: Jika kita bisa hidup bahagia, maka matipun `kita akan bahagia (p. 122).

TT: If we have a happy life, then our death will also be happy (p. 122).

'Hidup' which is in one word is repacked by a more expansively construction. Metaphorical construction represented by 'have a life' is used as the equivalent of 'hidup' in the TT. The TT is considered to be more metaphorical since incongruent form is used in the TT. 'Live' which is verb and is congruently construed as process is used to construe entity of 'life' in the TT.

\begin{tabular}{|c|c|c|c|c|c|c|}
\hline \multirow{4}{*}{ (7) } & \multirow{2}{*}{ ST } & kita & bisa & \multicolumn{2}{|l|}{ hidup } & bahagia \\
\hline & & Actor & \multicolumn{3}{|c|}{ Pro: Mat/action/operat } & Circum \\
\hline & \multirow{2}{*}{ TT } & we & $\varnothing$ & have & a life & happy \\
\hline & & Carrier & & Pro: Rel/Attrib & \multicolumn{2}{|c|}{ Attribute } \\
\hline
\end{tabular}

The following data are in the forms of material clause of action (Mat/action) using process of 'membimbing' and 'berguru'.

(8) ST: Ratu akan membimbing kita dengan baik (p. 96).

TT: Ratu then becomes our good guide (p. 95).

(9) ST: Dengan berguru kepada Ratu, kita akan melihat diri kita seberapa banyak gumpalan yang membelenggu diri kita (p. 128). 
TT: When Ratu becomes our teacher, we will see for ourselves how many handicaps we have (p. 128).

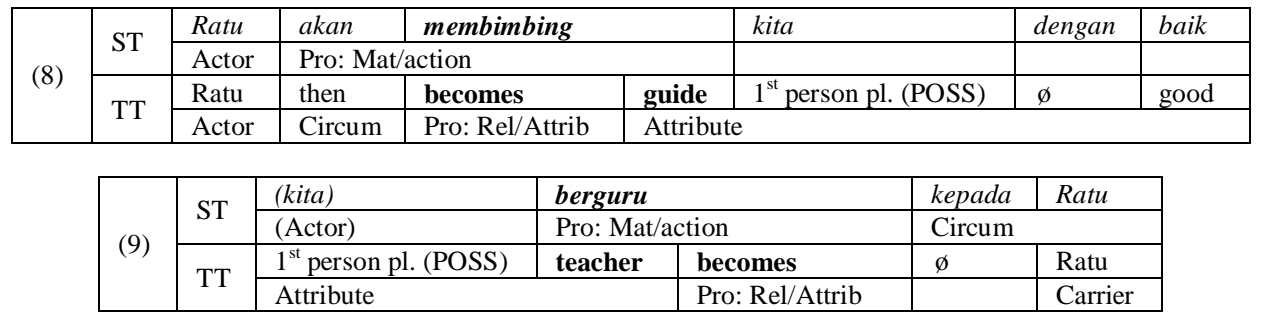

In the data above, relational clause of identification (Rel/ident) is used in the TT as the equivalent of the ST. The ST processes represented by 'membimbing' and 'berguru' are rendered by 'becomes guide' and 'becomes teacher' in the TT. This shows that one word of the ST is elaborated into more words in the TT. By this more expansively construction, the translator gives more emphasize to the function, as a guide or as a teacher, and not to the action, as to guide or to teach. More categorical TT is resulted by this construction.

\section{B. Diffusion and Shift of Expansion}

Expansion is a kind of translation shift in which a construction which has no explicit process is translated into a construction with a process. The following are data with nominalization forms in the ST and translated by drawing strategy of diffusion. $60)$.

(10) ST: Dalam persaingan, maka kita akan secara terus-menerus melihat kelebihan dan kelemahan kita dan ... (p.

TT: When we compete, we can constantly monitor our strength and weakness, as well as ... (p. 61).

(11) ST: Seperti perjalanan naik gunung kita merasakan kehausan dan kelelahan (p. 71).

TT: We feel thirsty and tired when we climb a mountain (p. 71).

(12) ST: Dengan latihan Bio energi Ratu Bagus secara aktif, maka kita akan bisa menghidupkan mesin alami kita di dalam diri (p. 153).

TT: When we actively train with Ratu Bagus Bio-Energy we can start up our natural engine (p. 153).

The ST in nominalization form has metaphorical construction since the process is not overtly stated. By the strategy of diffusion, the TT comes with process construction. The following data show the change of nominalization construction by material clause of action/operative. 'Persaingan', 'perjalanan and 'latihan' which are in one word are translated into more words. They become 'we compete', 'we climb' and 'we train' which are in the forms of material clause of action. Explicit agency arises by this construction and the TT becomes more dynamic by making the process more explicit.

\begin{tabular}{|l|l|l|l|l|}
\hline \multirow{3}{*}{$(10)$} & \multirow{2}{*}{ ST } & Dalam & \multicolumn{2}{l|}{ persaingan } \\
\cline { 2 - 4 } & & & \multicolumn{2}{|l|}{ Nominalization } \\
\cline { 2 - 4 } & \multirow{2}{*}{ TT } & When & we & compete \\
\cline { 3 - 4 } & & Actor & Pro: Mat/action \\
\hline
\end{tabular}

\begin{tabular}{|c|c|c|c|c|c|c|}
\hline \multirow{4}{*}{ (11) } & \multirow{2}{*}{ ST } & Seperti & \multicolumn{2}{|c|}{ perjalanan } & naik & gunung \\
\hline & & & \multicolumn{2}{|c|}{ Nominalization } & & \\
\hline & \multirow{2}{*}{ TT } & when & we & \multicolumn{2}{|c|}{ climb } & a mountain \\
\hline & & & Actor & \multicolumn{2}{|c|}{ Pro: Mat/action } & Scope \\
\hline
\end{tabular}

\begin{tabular}{|c|l|l|l|l|l|l|}
\hline \multirow{3}{*}{$(12)$} & \multirow{2}{*}{ ST } & Dengan & \multicolumn{2}{|l|}{ latihan } & Bio energi Ratu Bagus & secara aktif \\
\cline { 2 - 6 } & & & \multicolumn{2}{|l|}{ Nominalization } & & \\
\cline { 2 - 6 } & \multirow{2}{*}{ TT } & When & we & train & with Ratu Bagus & actively \\
\cline { 3 - 6 } & & Actor & Pro: Mat/action & Circum & Circum \\
\hline
\end{tabular}

Nominalization construction is also found in the data below.

(13) ST: Tanpa kekuatan, kita tidak akan bisa menolong orang lain (p. 162).

TT: If we don't have power, we cannot help others (p. 162).

(14) ST: Di dalam keheningan hidup, kita pasti bisa tertawa (p. 60).

TT: When our life becomes clear, we can laugh all the time (p. 60).

By the strategy of diffusion this construction turns into clause of relational. The types of relational clauses resulted are relational clause of possessive (Rel/poss) and relational clause of attributive (Rel/attrib). 'Kekuatan' and 'keheningan' are in nominalization construction in which adjective 'kuat' and 'hening' are construed as noun. In its translation this adjective is construed as quality and more words are needed in the TT. Explicit agency occurs represented by 'we' and explicit noun by 'our life'. 


\begin{tabular}{|c|c|c|c|c|c|c|}
\hline \multirow{4}{*}{ (13) } & \multirow{2}{*}{ ST } & & & Tanpa & \multicolumn{2}{|c|}{ kekuatan } \\
\hline & & & \multicolumn{4}{|c|}{ Nominalization } \\
\hline & \multirow{2}{*}{ TT } & If & we & don't & have & power \\
\hline & & & Carrier & \multicolumn{2}{|c|}{ Pro: Rel/Attrib } & Attribute \\
\hline
\end{tabular}

\begin{tabular}{|l|l|l|l|l|l|l|}
\hline \multirow{3}{*}{$(14)$} & \multirow{2}{*}{ ST } & Di dalam & keheningan \\
\cline { 2 - 6 } & & \multicolumn{4}{|l|}{} \\
\cline { 2 - 6 } & \multirow{2}{*}{ TT } & When & $\mathbf{1}^{\text {st }}$ person pl. (POSS) & life & becomes & clear \\
\cline { 3 - 6 } & & Carrier & Pro: Rel/Attrib & Attribute \\
\hline
\end{tabular}

Another kind of nominalization is found in the following data.

(15) ST: Dari keyakinan inilah spiritual akan berkembang (p. 69).

TT: Once we believe, our spirituality unfolds (p. 69).

This example shows that the verb 'yakin' is construed as entity represented by 'keyakinan'. In this translation, it is also rendered by a clause. That is mental clause of cognitive represented by process 'believe'. By repacking the ST with more expansively construction, the translator makes the agency more explicit.

\begin{tabular}{|l|l|l|l|l|l|}
\hline \multirow{3}{*}{$(15)$} & \multirow{2}{*}{ ST } & Dari & \multicolumn{2}{|l|}{ keyakinan } & inilah \\
\cline { 2 - 5 } & \multirow{3}{|c|}{ Nominalization } & \\
\cline { 2 - 5 } & \multirow{2}{*}{ TT } & Once & $\mathbf{1}^{\text {st }}$ person pl. & believe & $\emptyset$ \\
\cline { 3 - 5 } & & Senser & Pro: Mental/cognitive & Phenom \\
\hline
\end{tabular}

\section{Diffusion and Shift from Mental into Non-mental Clause}

Strategy of diffusion also results in the shift from mental into non-mental clause. Mental clauses of cognitive represented by process 'sadari' (or 'menyadari') and 'ketahui' (or 'mengetahui') are found in the data below.

(16) ST: Bagaimana kebesaran Tuhan itu kita sadari? (p. 3).

TT: How can we become conscious of the mightiness of God? (p. 3).

(17) ST: Tapi ketahuilah, itulah sebenarnya bentuk perubahan yang ada di dalam diri (p. 71).

TT: But be aware that this is really a sign of internal change (p. 71).

These types of clause turn into relational clause of attributive (Rel/attrib) in the TT if the strategy applied is strategy of diffusion. The TT uses more words to translate clause of mental, 'sadari' is rendered as 'become conscious' and 'ketahui' as 'be aware'. This construction makes the TT more static.

\begin{tabular}{|l|l|l|l|l|l|l|l|l|}
\hline \multirow{3}{*}{$(16)$} & \multirow{2}{*}{ ST } & Bagaimana & kebesaran & Tuhan & & kita & sadari & \\
\cline { 2 - 9 } & & \multirow{2}{*}{ TT } & How & Phenom & & Senser & Pro: Mental/cognitive & \\
\cline { 3 - 9 } & & the mightiness & God (POSS) & can & we & become & conscious \\
\hline
\end{tabular}

\begin{tabular}{|l|l|l|l|l|l|}
\hline \multirow{3}{*}{$(17)$} & \multirow{2}{*}{ ST } & Tapi & $($ kamu $)$ & ketahuilah \\
\cline { 3 - 5 } & & & Senser & Pro: Mental/cognitive \\
\cline { 2 - 5 } & \multirow{2}{*}{ TT } & But & (you) & be & aware \\
\cline { 3 - 5 } & & Carrier & Pro: Rel/attrib & Attribute \\
\hline
\end{tabular}

To summarize, the strategy of diffusion applied to translate the meditation text from Indonesian into English results in some consequences. One of the impacts is that material clause in the Indonesian text becomes non-material clause in English. By this change, the English text becomes more static and categorical since the process used does not indicate an action. Clause with relational process using process of 'becomes' followed by noun 'teacher' will be more static compared with the clause having material clause of 'berguru'. The strategy of diffusion also makes the English text more explicit. It is when the translation concerns with nominalization construction in the Indonesian text. The nominalization construction is repacked without the change of meaning and the agent and process become explicit in its translation. 'When we compete ...' is more explicit than 'dalam persaingan, ...'. Another consequence of the strategy of diffusion is that a clause with mental meaning is expressed by using relational clause, such as found in the translation of 'kita sadari' becoming 'we become conscious'. This change also results in the change of meaning of the English text. The English text is more static compared with its Indonesian text.

\section{CONCLUSION}

The strategy of diffusion in the translation of meditation text from Indonesian into English results in the shifts of transitivity structure. The shifts of transitivity structure induced by this translation strategy include dematerialization, expansion and the shift from mental into non-mental clause. These shifts make the clause types of the Indonesian texts change in their translation. The strategy of diffusion also affects its translation. The English text becomes more static, more categorical and more explicit. 


\section{ACKNOWLEDGMENTS}

I would like to thank Prof. Dr. Ketut Artawa, M.A. for his expert advice due to the syntactic analysis of my work.

\section{REFERENCES}

[1] Aghagolzadeh, Ferdws. (2012). The Analysis of English-Persian Legal Translations Based on Systemic Functional Grammar Approach (SFG). Theory and Practice in Language Studies, Vol. 2, No. 1, pp. 126-131. ISSN 1799-2591. doi: 10.4304/tpls.2.1.126-131.

[2] Bai, Zhihong. (2018). On Translation Strategies of English Movie Titles. Journal of Language Teaching and Research, Vol. 9 , No. 1. pp. 119-124. DOI: http://dx.doi.org/10.17507/jltr.0901.15.

[3] Baker, Mona. Routledge. (2001). Encyclopedia of Translation Studies. New York: Routledge.

[4] Darani, Laya Heidari. (2014). Persuasive style and its realization through transitivity analysis: A SFL . Procedia - Social and Behavioral Sciences 158, 179 - 186. doi: 10.1016/j.sbspro.2014.12.066.

[5] Halliday, M.A.K. \& C. M. I. M. Matthiessen. (2014). Halliday's Introduction to Functional Grammar. Fourth Edition. New York: Routledge.

[6] House, Juliane. (2015). Translation Quality Assessment. New York: Routledge.

[7] Ida Pandita Mpu Nabe Parama Daksa Natha Ratu Bagus. (2012). Butir-Butir Kebijaksanaan: Titian Hidup Sehat dengan Meditasi Bio-Energi Ratu Bagus. Karangasem: Ashram Ratu Bagus.

[8] Malone, J.L. (1988). The Science of Linguistics in the Art of Translation. Albany: State University of New York Pess.

[9] Pérez, Maria Calzada. (2007). Transitivity in Translating. Bern: Peterlang AG, International Academic Publisher.

[10] Stacey, Marianne. (2014). Pearls of Wisdom: The Path of a Healthy Life with Ratu Bagus Bio-Energy Meditation. Karangasem: Ratu Bagus Ashram.

Made Susini was born in Singaraja, Bali, Indonesia. She is a lecturer in English Department at Warmadewa University, Bali, Indonesia. She obtained her Master Degree in Applied Linguistics (Translation) in 2005 from Udayana University, Bali, Indonesia. She is currently a candidate doctorate in Linguistics at Udayana University and her main research is focused on Linguistic Translations.

I Nengah Sudipa is a Professor in Linguistics at Udayana University, Bali, Indonesia. He received his Master in Linguistics from Monash University in 1988 and his Doctorate in Linguistics from Udayana University, Bali, Indonesia in 2004. His research interests include a wide range of topics related to linguistics. He has supervised many theses and doctorate dissertations. He has participated in numerous national and international conferences and has written a lot of books and articles.

I Nyoman Suparwa is a Professor in Linguistics at Udayana University, Denpasar, Bali, Indonesia. He is currently a vice Dean I at Faculty of Arts, Udayana University. He obtained his Master in Linguistics from Hasanuddin University, Indonesia in 1990 and his Doctorate in Linguistics from Udayana University in 2007. He has been a supervisor for numerous theses and doctorate dissertation. His research interests are phonology, psycholinguistics and language teaching. He has published many articles and book and actively participated in national and international conference and academic workshop.

Ida Ayu Made Puspani is a senior lecturer of English Department, Faculty of Arts at Udayana University, Bali, Indonesia. She obtained her Master in Applied Linguistics (Translation) in 2003 and her Doctorate in 2010 also in Applied Linguistics (Translation) in 2010. Both were received from Udayana University, Bali, Indonesia. Her research interests are translation and language teaching. Her publications include studies on translation (2013-2014), language teaching for young learners (2011) and court interpreting in Denpasar Court (2010). She has participated in many national and international conferences and workshops. 